\title{
PERMASALAHAN DAN POTENSI PESISIR DI KABUPATEN SAMPANG
}

\section{SAMPANG'S COASTAL PROBLEMS AND POTENTIALS}

\author{
Aries Dwi Siswanto*, Wahyu Andy Nugraha
}

Program Studi Ilmu Kelautan Universitas Trunojoyo Madura

Jl. Raya Telang PO.BOX 2 Kamal, Bangkalan, Madura, Jawa Timur

*Corresponding author e-mail: ariesdwisiswanto@yahoo.co.id

Received: February 1, 2016/Accepted: March 29, 2016

\begin{abstract}
One area that has progressive economic value and environmental degradation possibility is a dynamic areas of coastal areas. These characteristics is interesting in the perspective of management and utilization of marine resources and fisheries. The rapid development of the Sampang regency required the government to focus and provide greater attention to minimize the ecological pressures that affect the carrying capacity of the environment, particularly in coastal areas. This study aims to gather information about the problem and the potential that exists in coastal areas of Sampang. Data taken by interviewing respondents lived in coastal communities during April 2015 and the results of the questionnaire were analyzed descriptively. The problems identified include land requirement, the overlapping use, the threat of pollution and environmental degradation, and zoning; whereas the potential that exists include salt, marine tourism, mariculture, and the development of industrial areas and ports. The potential problems identified in coastal areas and beaches in Sampang relatively identical to the Bangkalan. It needs a comprehensive solution to minimize the existing impact as well as efforts to optimize utilization to achieve integrated coastal zone management.
\end{abstract}

Keywords: coastal, CZM, problem, potential, Sampang

\section{ABSTRAK}

Salah satu wilayah yang memiliki nilai ekonomi progresif sekaligus peluang degradasi lingkungan sehingga disebut daerah dinamis adalah wilayah pantai dan pesisir. Karakteristik ini menjadi sesuatu yang menarik dalam perspektif pengelolaan dan pemanfaatan sumberdaya kelautan dan perikanan. Pesatnya perkembangan tersebut menuntut pemerintah kabupaten Sampang untuk focus dan memberikan perhatian lebih besar sebagai upaya untuk meminimalkan tekanan ekologis yang berpengaruh terhadap daya dukung lingkungan, khususnya di wilayah pesisir. Penelitian ini bertujuan untuk mengumpulkan informasi tentang permasalahan dan potensi yang ada di wilayah pesisir di Kabupaten Sampang. Data diambil dengan metode interview dengan responden masyarakat di daerah pesisir selama bulan April 2015 dan hasil kuisioner dianalisa secara deskriptif. Hasil analisa kuisioner menunjukkan permasalahan yang teridentifikasi meliputi kebutuhan lahan, overlapping wilayah pemanfaatan, ancaman pencemaran dan degradasi lingkungan, dan zonasi pemanfaatan; sedangkan potensi yang ada di wilayah pesisir Kabupaten Sampang meliputi garam, wisata bahari, budidaya laut, dan pengembangan kawasan industri dan pelabuhan. Permasalahan maupun potensi yang teridentifikasi di wilayah pesisir dan pantai di Kabupaten Sampang relative identik dengan Kabupaten Bangkalan. Untuk itu, perlu penyelesaian komprehensif sehingga dapat meminimalkan dampak yang ada sekaligus sebagai upaya untuk mengoptimalkan pemanfaatan dalam upaya mewujudkan pola pengelolaan wilayah pesisir terpadu.

Kata kunci: permasalahan, pesisir, potensi, PWP, Sampang 


\section{PENDAHULUAN}

Degradasi lingkungan merupakan salah satu masalah pelik sekaligus klasik yang dihadapi oleh pemerintah propinsi/kabupaten/kota, khususnya di daerah pesisir dan pantai diduga akibat pesatnya perkembangan wilayah oleh berbagai hal. Tingginya dinamika wilayah pesisir dan pantai menjadi fokus utama dalam pengelolaan konflik dan kepentingan sebagai upaya untuk meminimalkan pengaruh degradasi lingkungan. Keberlimpahan sumberdaya di wilayah pesisir dan pantai menjadi daya tarik, sehingga berpengaruh terhadap faktor fisika, sosio-ekonomi, dan politik yang saling berkaitan, sekaligus dinamika sistem pantai dalam upaya pengelolaan wilayah pesisir secara terpadu dan berkelanjutan (ICZM) (Solway, 2006; Varghese et al., 2008). Harapannya adalah optimalisasi dalam pemanfaatan dan pengelolaan sumberdaya di Indonesia sehingga tercapai perencanaan pengelolaan pesisir (Pratikto, 2003) yang membuka peluang meningkatkan percepatan pertumbuhan sosio-ekonomi sekaligus melindungi keseimbangan ekologi. ICZM dapat dijadikan sebagai media kontrol (Suman, 2007) sehingga dapat mengurangi tekanan ekologi.

Urgensi UU 27/2007 jo 01/2014 menjadi landasan dalam penyusunan sekaligus implementasi RTRW dengan salah satu upaya awal yang dilakukan adalah identifikasi permasalahan dan potensi. Tujuannya adalah untuk menggali informasi masalah dan potensi sebagai dasar dalam penyusunan maupun implementasi RTRW.

Kabupaten Sampang merupakan salah satu sentra penghasil garam terbesar di pulau Madura. Potensi ini belum dioptimalkan, sehingga belum memberikan kontribusi nyata terhadap peningkatan kesejahteraan masyarakat. Kondisi ini diduga berkaitan dengan belum optimalnya implementasi UU 27/2007 jo 01/2014, khususnya dalam pengelolaan wilayah pesisir dan pantainya. Konsep RTRW yang dibangun harus didasarkan pada indikator yang jelas, sehingga perlu diketahui tingkat pemahaman masyarakat atas substansi UU 27/2007 jo 01/2014 dengan melakukan identifikasi masalah dan potensi untuk melihat kesesuaian kebijakan yang ada.

\section{MATERI DAN METODE}

Penelitian dilakukan di daerah pesisir dan pantai di Kabupaten Sampang pada bulan April 2015. Data dikumpulkan dengan menggunakan metode wawancara dan bersifat studi kasus dengan responden masyarakat untuk mengetahui permasalahan dan potensi di daerah pesisir dan pantai di Kabupaten Sampang sebagai bentuk dari implementasi UU 27/2007 jo 01/2014. Pendekatan penelitian secara positivistic digunakan untuk mengkaji realita dan mencoba mencarikan solusinya. Kuisioner dikembangkan dan diturunkan dari beberapa indikator (Fabbri, 1998) dan dievaluasi dari substansi UU 27/2007 jo 01/2014 (Idris, 2010; Siswanto et al., 2010). Pengambilan data dilakukan dengan menggunakan metode non probability sampling dengan purposive sampling dengan unit populasi adalah masyarakat nelayan di beberapa kecamatan di wilayah pesisir di Kabupaten Sampang. Analisa data dilakukan secara deskriptif untuk mengidentifikasi permasalahan sekaligus potensi yang ada di lokasi penelitian.

\section{HASIL DAN PEMBAHASAN}

Hasil analisa atas interview terhadap responden masyarakat di Kabupaten Sampang menunjukkan bahwa responden terdiri atas $41.2 \%$ laki-laki dan $58.8 \%$ perempuan dengan kisaran usia 25-34 tahun sebanyak 12\%, 35-44 tahun sebanyak 35\%, 45-54 tahun sebanyak $24 \%$, serta usia $\geq 55$ tahun sebanyak $29 \%$, yang menunjukkan dominasi usia produktif sebesar $71 \%$. Tingkat pendidikan responden didominasi oleh $82 \%$ SD, $12 \%$ SLTP, dan $6 \%$ SLTA. Sebaran responden berdasarkan jenis pekerjaan yaitu profesi nelayan sebesar $42 \%$, pedagang dan ibu rumah tangga masing-masing $12 \%$, petani $24 \%$, dan lainnya (28\%). Responden umumnya adalah penduduk asli yang telah menetap lebih dari 20 tahun. 
ISSN: 1907-9931 (print), 2476-9991 (online)

Permasalahan yang teridentifikasi yaitu kebutuhan lahan, overlapping wilayah pemanfaatan, ancaman pencemaran dan degradasi lingkungan dan zonasi pemanfaatan. Masalah kebutuhan lahan diduga merupakan ekses dari pembangunan Jembatan Suramadu yang berpotensi menaikkan harga lahan sehingga membuka peluang adanya konversi lahan dan reklamasi. Kegiatan ini seringkali berimplikasi negatif karena berpotensi merusak bahkan menghilangkan ekosistem mangrove, sehingga menurunkan kemampuan daya dukung lingkungan. Konsekuensi lanjutannya adalah menimbulkan ekonomi biaya tinggi, khususnya untuk melindungi berbagai infrastruktur penting diwilayah pesisir.

Selain konversi lahan, reklamasi menjadi salah satu solusi untuk memenuhi kebutuhan lahan didaerah pesisir dan telah diterapkan. Kecamatan Camplong merupakan salah satu daerah yang mengalami dua hal tersebut, yaitu konversi lahan dan reklamasi. Daya dukung lingkungan menjadi turun disebabkan daerah sepanjang pantai di Kecamatan Camplong mengalami abrasi akibat lokasinya terekspose dan terbuka terhadap serangan gelombang laut. Jika kondisi tersebut tidak memperoleh penanganan yang memadai, maka beberapa infrastruktur, seperti jalan raya (utama) di sisi selatan akan rusak.

Permasalahan kedua adalah overlapping wilayah pemanfaatan. Tumpang tindih wilayah pemanfaatan terjadi di daerah daratan di sekitar pesisir dan pantai maupun di wilayah perairannya. Kondisi tersebut muncul diduga erat kaitannya dengan kepentingan ekonomi sehingga berpengaruh terhadap ketersediaan lahan. Hal ini menyebabkan overlapping didaerah daratan dalam bentuk konversi hutan bakau (seharusnya menjadi daerah green belt untuk pelindung alamiah pantai terhadap serangan gelombang dan arus yang dapat menyebabkan abrasi) telah dialihfungsikan untuk berbagai kepentingan (seperti pemukiman maupun industry). Overlapping diperairan dalam bentuk konflik horizontal nelayan dalam penentuan dan pemanfaatan wilayah penangkapan ikan.

Berbagai kondisi diatas dapat meningkatkan degradasi lingkungan di daerah sekitar pesisir dan pantai. Beberapa kegiatan industri berpotensi untuk membuang limbah ke perairan laut jikalau tidak memiliki IPAL yang memadai. Limbah buangan dari berbagai aktifitas akan terakumulasi di perairan. Untuk memperkuat asumsi tersebut disarankan untuk melakukan penelitian terkait, baik dari sisi biologi, fisika, kimia, maupun geologi. Selain itu, topografi wilayah di Kabupaten Sampang berupa cekungan dibeberapa daerah menyebabkan banjir, baik pada waktu musim hujan maupun kemarau (yang sering disebut sebagai $\mathrm{ROB}=$ banjir air laut karena pasang tertinggi), sehingga perlu solusi untuk meminimalkan kerugian yang diderita masyarakat. Adanya kecenderungan degradasi lingkungan memberikan pengaruh terhadap zonasi pemanfaatan di wilayah pesisir dan pantai.

Dalam penentuan rencana zonasi, khususnya pemanfaatan, perlu dan selalu mempertimbangkan banyak aspek dan kepentingan, sehingga membuka peluang adanya kompromi yang memungkinkan untuk menimbulkan pelanggaran (perda/perbub atau sejenisnya) terkait RTRW wilayah pesisir dan pulau-pulau kecil.

Potensi yang ada di wilayah Kabupaten Sampang, meliputi garam, wisata bahari, buddaya laut, dan pengembangan kawasan industri terpadu. Garam menjadi salah satu potensi yang harus dikembangkan dengan optimal karena Kabupaten Sampang merupakan salah satu kabupaten penghasil garam terbesar di pulau Madura. Usaha tambak garam dilakukan secara tradisional dan modern. Masyarakat mengelola usaha tambak garam secara tradisional, sedangkan pengelolaan usaha tambak garam secara modern dilakukan oleh beberapa perusahaan, diantaranya PT Garam (persero) maupun perusahaan swasta lainnya. Pengelolaan usaha tambak garam akan memberikan nilai positif terhadap upaya peningkatan kesejahteraan masyarakat apabila dilakukan dengan manajemen dan strategi yang baik. Keberadaan tambak garam membuka peluang untuk dijadikan salah satu ikon wisata bahari di pulau Madura umumnya dan di Kabupaten Sampang khususnya. 
ISSN: 1907-9931 (print), 2476-9991 (online)

Pengembangan kawasan wisata bahari berbasis tambak garam perlu komitmen dan upaya lebih keras dari pemerintah kabupaten maupun stakeholder. Salah satu bentuk komitmen pemerintah kabupaten adalah dalam bentuk penyediaan infrastruktur utama maupun penunjang. Selain peluang pengembangan usaha tambak garam menjadi wisata bahari, keberadaan Pulau Mandangin sebagai satu-satunya pulau yang dimiliki oleh Kabupaten Sampang merupakan aset berharga yang memungkinkan untuk dikembangkan menjadi daerah wisata bahari, khususnya untuk wisata bawah air karena potensi ekosistem terumbu karang yang cukup menjanjikan. Hal ini juga perlu dukungan masyarakat, khususnya dalam menjaga dan melestarikan ekosistem, agar menjadi daerah yang nyaman, aman, dan tenang, sehingga menarik wisatawan untuk berkunjung.

Untuk menunjang rencana pengembangan tersebut, pemerintah kabupaten perlu untuk melakukan kajian lebih mendalam sehingga memperoleh gambaran komprehensif dalam upaya pemanfaatan dan pengelolaan sumberdaya agar tidak menurunkan daya dukung lingkungan. Kualitas dan kondisi lingkungan akan berpengaruh terhadap kegiatan lainnya, seperti budidaya laut. Kabupaten Sampang merupakan salah satu daerah penghasil lorjuk (Solen sp) terbesar diantara empat kabupaten di Pulau Madura (Abida et al., 2013; Wahyuni et al., 2015). Permasalahannya, biota ini belum berhasil dibudidayakan (Abida et al., 2013). Selain lorjuk, rumput laut merupakan peluang usaha budidaya yang layak dikembangkan dengan mempertimbangkan luasan daerah perairan laut di Kabupaten Sampang. Seperti halnya upaya yang dimungkinkan dalam menata usaha tambak garam, kedua usaha budidaya ini mempunyai peluang untuk dikembangkan sekaligus dalam kegiatan pengembangan wisata bahari. Berbagai usaha dan upaya pengelolaan sumberdaya diatas perlu untuk mempertimbangkan integrasi dengan usaha industri sehingga dapat dikembangkan kawasan industri terpadu pada kawasan tertentu di daerah pesisir. Kebedaraan industri, baik jasa maupun produksi, sehingga perlu dipertimbangkan lokasi dan ketersediaan lahan serta daya dukung lingkungan.

Permasalahan dan potensi yang ada di wilayah pesisir dan pantai di Kabupaten Sampang sudah seharusnya menjadi perhatian serius dari pemerintah kabupaten melalui SKPD agar diperoleh solusi penyelesaiannya sehingga dapat mengurangi tekanan ekologis dan menjadi dasar serta pertimbangan bagi pemerintah kabupaten dalam pengembangan dan pengelolaan wilayah melalui penyusunan RTRW. Implementasi RTRW yang baik akan meningkatkan daya saing, sehingga penyusunan dan implementasi RTRW sebaiknya tetap berpegang pada konsep ICZM (Pratikto, 2003; Solway, 2006).

\section{KESIMPULAN DAN SARAN}

Hasil analisa kuisioner menunjukkan permasalahan yang teridentifikasi meliputi kebutuhan lahan, overlapping wilayah pemanfaatan, ancaman pencemaran dan degradasi lingkungan, dan zonasi pemanfaatan; sedangkan potensi yang ada di wilayah pesisir Kabupaten Sampang meliputi garam, wisata bahari, budidaya laut, dan pengembangan kawasan industri dan pelabuhan. Permasalahan maupun potensi yang teridentifikasi di wilayah pesisir dan pantai di Kabupaten Sampang relative identik dengan Kabupaten Bangkalan. Untuk itu, perlu penyelesaian komprehensif sehingga dapat meminimalkan dampak yang ada sekaligus sebagai upaya untuk mengoptimalkan pemanfaatan dalam upaya mewujudkan pola pengelolaan wilayah pesisir terpadu.

\section{UCAPAN TERIMA KASIH}

Terimakasih disampaikan kepada DP2M DIKTI dalam pendanaan untuk penelitian Hibah Bersaing tahun 2015 dan Tim Survey (Sdr. Moch. Syaifullah, S.ST.Pi, Sdr. Yuniar Ade Candra, S.Si, Sdr. Moh. Yusuf B, S.Kel, Sdri. Dewy Septiyanti Yolanda, S.Si, Sdr. Aditya Januar, dan Sdr. Saifuddin di Pusat Studi Ilmu Kelautan Universitas Trunojoyo Madura). 


\section{DAFTAR PUSTAKA}

Abida, I. W, Wahyuni, E. A., \& Efendy, M. (2013). Pengembangan pola marikultur sebagai suatu upaya pencegahan overfishing dan peningkatan produksi kerang lorjuk (Solen spp). Laporan Penelitian Hibah Bersaing. LPPM. Universitas Trunojoyo Madura.

Idris, I. (2010). Arahan percepatan penyusunan peraturan pelaksanaan UU nomor 27 tahun 2007 tentang pengelolaan wilayah pesisir dan pulau-pulau kecil. Lokakarya Perencanaan Pengelolaan Wilayah Pesisir dan Pulau-Pulau Kecil, Surabaya, Maret 2010.

Fabbri, K. P. (1998). A methodology for supporting decision marking in integrated coastal zone management. Ocean and Coastal Management, 39, 51-62.

Pratikto, W. A. (2003). Learning through parthnerships in the contex of decentralized integrated coastal management policy in Indonesia. Coastal Zone Meeting, Baltimore, Maryland, USA.

Siswanto, A. D., Pratikto, W. A., Suntoyo, Sambodho, K., \& Nurlela, S. (2010). Studi awal implementasi UU 27/2007 di Kotamadya Surabaya. Prosiding Seminar Nasional Teori dan Aplikasi Teknologi Kelautan. Desember. ITS-Surabaya.

Solway Firth GDSPDS Coastal Information system /http://www.abdn.ac.uk/_geo402/glossary.htmS (last visited on June 5, 2006).

Suman, D. (2007). Development of an integrated coastal management plan for the Gulf of San Miguel and Darien Province, Panama: lessons from the experience. Ocean and Coastal Management, 50, 634-660.

Wahyuni, E. A., Insafitri, Ciptadi, G., \& Ihsan, M. N. (2015). Sebaran kerang pisau (Solen sp) di perairan Kabupaten Sampang, Madura, Jawa Timur. Prosiding Simposium Nasional Kelautan dan Perikanan II. FIKP. Universitas Hasanuddin. Makasar. 